\title{
Luft fra tarm til hals
}
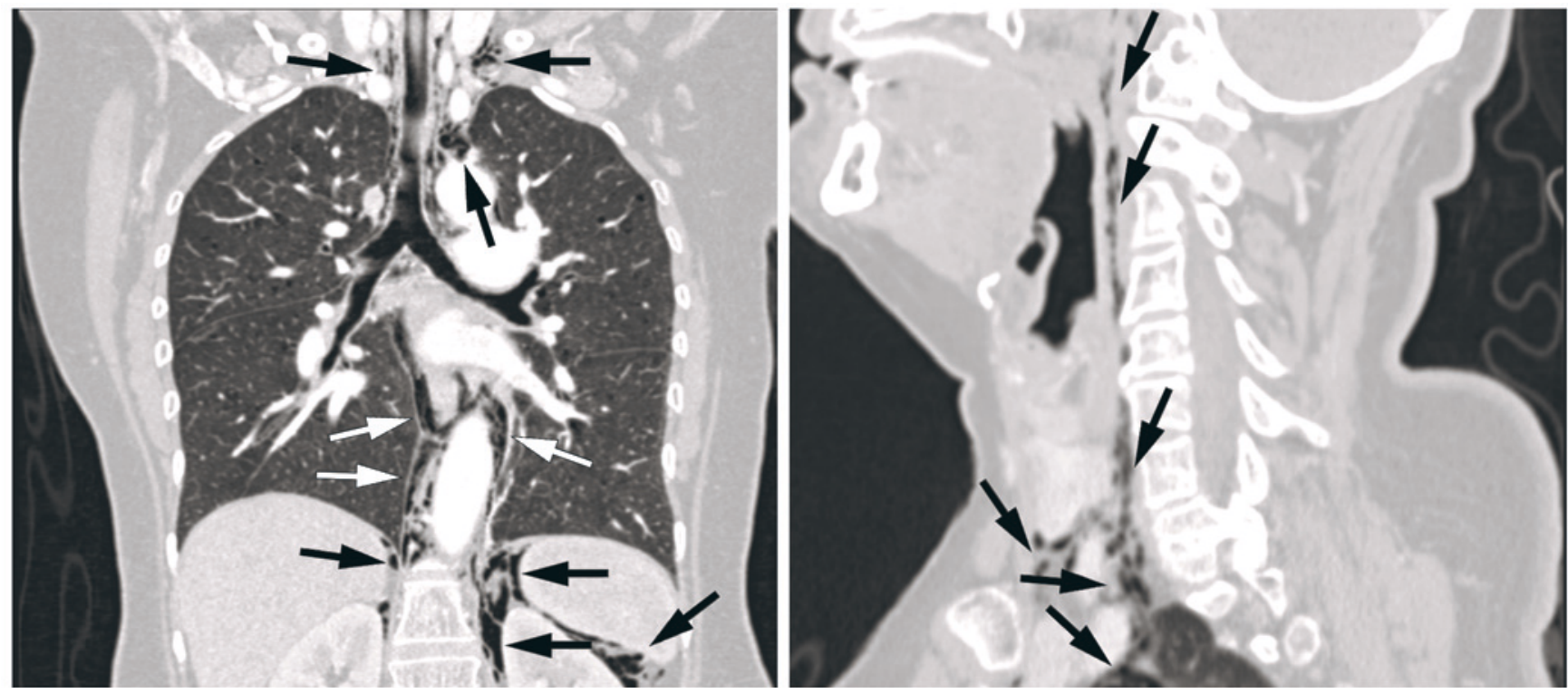

En kvinne i 60-årene kontaktet legevakten grunnet halssmerter og feber. Når hun snakket, svelget og beveget hodet, ble smertene forverret. Smertene hadde startet dagen før, kun få timer etter at hun hadde fått fjernet en polypp i rektum ved sitt lokalsykehus. Hun var øm i magen, men ømheten forsvant når hun var i ro.

Ved undersøkelse på legevakten var hun subfebril, oropharynx var uten anmerkning og hennes abdomen var bløt med normale tarmlyder, men diffust øm ved palpasjon. CRP var $200 \mathrm{mg} / \mathrm{l}$. Muligheten for en rektal perforasjon etter polyppektomi ble overveid, og det ble gjort en røntgen oversikt abdomen som ga mistanke om fri luft retroperitonealt. En CTundersøkelse av collum, thorax og abdomen bekreftet fri luft (se piler) i retroperitoneum, mediastinum og retrofaryngealt, hvor sistnevnte forklarte hennes halssmerter. Pasienten ble behandlet konservativt med intravenøs antibiotika og faste, og ble utskrevet fra sykehuset seks dager senere.

Forklaringen på at luft kan spre seg på denne måten er de potensielle anatomiske rommene som strekker seg fra retroperitoneum, gjennom mediastinum og opp til halsen. Den økende bruken av diagnostiske og terapeutiske endoskopier gjør at man bør være oppmerksom på komplikasjoner, og at perforasjon med retroperitoneal luft kan gi uventede symptomer (1).

Pasienten har gitt samtykke til at artikkelen blir publisert.

\section{Erik Magnus Berntsen}

erik.berntsen@stolav.no

Klinikk for bildediagnostikk

St. Olavs hospital

og

Institutt for sirkulasjon og bildediagnostikk

Norges teknisk-naturvitenskapelige universitet

\section{Tobias S. Slørdahl}

Medisinsk klinikk

St. Olavs hospital

og

Institutt for kreftforskning og molekylærmedisin Norges teknisk-naturvitenskapelige universitet
Erik Magnus Berntsen (f. 1982) er ph.d., førsteamanuensis II i radiologi og lege i spesialisering i radiologi.

Forfatter har fylt ut ICMJE-skjemaet og oppgir ingen interessekonflikter.

Tobias S. Slørdahl (f. 1982) er ph.d., postdoktor, førsteamanuensis II og lege i spesialisering $\mathrm{i}$ indremedisin.

Forfatter har fylt ut ICMJE-skjemaet og oppgir ingen interessekonflikter.

\section{Litteratur \\ 1. Panteris V, Haringsma J, Kuipers EJ. Colonoscopy perforation rate, mechanisms and outcome: from diagnostic to therapeutic colonoscopy. Endoscopy 2009; 41: 941-51.}

Mottatt 1.6. 2015 og godkjent 29.6. 2015. Redaktør: Lise Mørkved Helsingen. 